DOI: https://doi.org/10.47405/mjssh.v6i6.820

\begin{tabular}{|c|c|}
\hline$F=$ & Malaysian Journal of Social Sciences and Humanities (MJSSH) \\
\hline Malaysian Journal of & Volume 6, Issue 6, June 2021 \\
\hline (MJ - SSH) & e-ISSN : 2504-8562 \\
\hline & $\begin{array}{l}\text { Journal home page: } \\
\text { www.msocialsciences.com }\end{array}$ \\
\hline
\end{tabular}

\title{
Development Of Geobot Games in Teaching and Facilitation of Form Four Geographical Skills Topics
}

Mohamad Amran Bin Manining ${ }^{1}$, Soon Singh A/L Bikar Singh1

${ }^{1}$ Faculty of Psychology and Education, Universiti Malaysia Sabah (UMS)

Correspondence: Mohamad Amran Bin Manining (insp pencen@yahoo.com)

\begin{abstract}
The suitability of Teaching and Facilitation Strategies (PDPc) will be able to create effective and fun learning for students in schools where the ability of teachers to plan and implement various PdPc strategies is able to optimize a learning session. PDPc's student -centered strategy can provide opportunities for students to submit opinions, cultivate the attitude of always seeking knowledge and learning throughout life. Student -centered learning that requires the active involvement of students in finding and investigating problems, constructing hypotheses, designing experiments, collecting data as well as drawing conclusions to solve problems can be implemented through game -based learning. While the teacher only acts as a facilitator. This study is a design and development research using the ADDIE Model. Findings show that the implementation of the ADDIE Model in the development of Geobot Game Module makes the development of modules can be carried out systematically and produce modules relevant to the Secondary School Standard Curriculum for Geography form four set by the Ministry of Education Malaysia.
\end{abstract}

Keywords: games, geographical skills, ADDIE model, KSSM

\section{Introduction}

Geography skills is a sub -field of knowledge in the subject of Geography that gives students the opportunity to make explorations to help them understand the knowledge of Geography. Geographical skills are learned through the titles of direction, position, scale, distance, area, elevation, cross section, physical land view and cultural land view in topographic maps as well as graphs, pie charts and photographs. Through this topic studied, students can master skills such as making observations, measuring, recording, conveying, and interpreting information. In this regard, the researchers have developed a robot learning material called Geobot -based game in the form of modules that not only serve as a platform to improve student's goal orientation and collaborative but also can have an impact on the improvement of student's achievement. The use of learning modules is to provide a conceptual model for learning in minimizing the need for the use of more verbal conventional learning techniques (Robinson, 1972). analysis, design, development, implementation, and evaluation phases.

\section{Literature Review}

Media and learning technologies have greatly influenced the pattern of education around the world. This can be seen through the evolution in educational methods in China which emphasizes the need for the 
latest teaching approaches to replace traditional learning in order to prepare more students to succeed in the 21 st century. Thus, the use of robotics, for example, is used as a measure of innovation in teaching and learning at the international level. Learning through robotics is seen as one of the ways to attract the interest of students who struggle through conventional learning in school. Studies are also not limited to any learning approach. This is due to the nature of robotics itself which can be flexible and highly inclusive for the gifted students and also the students with learning difficulties.

In addition, the game robot-based learning process can be used as a medium for the students to develop themselves optimally, social processes with other friends, and problem-solving skills when solving a task in a game that has been designed (Jusof, 2019). The game -based learning process has expanded its function in order to affect students not only the aspects of achievement or mastery of the content but also encompass the aspects of humanity and ethics (Škuta \& Kostolányová, 2018). However, the study of the use of game robots is currently more focused on Science, Mathematics and Engineering subjects designed for students to acquire skills in the 21st century (Ortiz, 2015).

\section{Research Methodology}

This study is a design and development research (Richey \& Klein, 2009) using the ADDIE Model (Branch 2009). It is uses purposive sampling and the study participants consisted of three expert panel consisting of Excellent Geography teachers at SPM level as well as and 31 form four students who took Geography as an elective. While data were obtained using a questionnaire instrument. Questionnaires for experts were analyzed using the module validity calculation formula (Noah \& Ahmad, 2005), while questionnaires for students were analyzed using IBM SPSS Statistics (Version 23.0) to obtain Croanbach's Alpha module reliability.

In this study, the construction of the module reliability questionnaire items was built based on the objectives for the activities (Sidek Mohd Noah). Russell (1974) stated that to test the reliability of a module, the researcher needs to see the ability of the sample (the students) to follow the steps of each activity in the module successfully. The reliability questionnaire format uses a modified format from the Game Robot Module module reliability questionnaire (Shakir, 2018). In addition too, the evaluation of the content reviewer of the Geobot Game Module was done through a panel of experts to ensure that this module is suitable for use in Geography Skills' PDPc for form four students. The expert panel consists of excellent teachers of Geography at SPM level. Objective determination was used as an item to determine the validity of the module to obtain the value of agreement by all experts.

\section{ADDIE'S Model in A Geobot Game}

The ADDIE model has been incorporated in the development of the Form Four Geography Skills Geobot module which is one of the instructional design models that is often the basis for other instructional design models. In general, the ADDIE model consists of the phases of Analysis (Analysis), Design (Design), Development (Development), Implementation (Implementation) and Evaluation (Evaluation (Branch, 2009).

The five phases found in the ADDIE Model in developing GeoBot are:

\section{1) Analysis}

Geobot Module analysis will take into account the report on the quality of students' answers in SPM 2013 and 2014 examinations for Geography, among the recommendations given by the examiner is that students need to do more mapping training in Geography skills to identify important areas related to a topic such as cities, ports, agricultural areas, densely populated or sparsely populated. Through these recommendations, game-based learning design by taking into account the factors that will affect 
cognitive processing namely lesson content, how content is delivered and game-based learning mechanics to facilitate students to achieve desired cognitive goals (Khairudin et al. 2017).

\section{2) Design}

The researcher has set some specific teaching objectives using the Geobot game module in the learning of Form 4 Geography Skills as follows;

i. Increase the minimum score of student goal orientation

ii. Improve the minimum score of the collaborative level of students

iii. Improve the minimum score of student achievement in the topic of Geography skills

\section{Geobot Game Design}

GeoBot is designed according to the theme of interactive learning for the subject of geography. Technically, GeoBot is designed using 'AutoCad' software which is a computer -aided design software to further simplify the design method. GeoBot is also a mobile robot using four wheels to further facilitate movement when used for teaching modules. The uniqueness of the GeoBot can also be seen through the design of the compass that will move according to the forward, backward, left and right movement of the GeoBot. Apart from that, GeoBot is also built using '3D printing' technology, this is to attract students who like the unique designs and color themes.

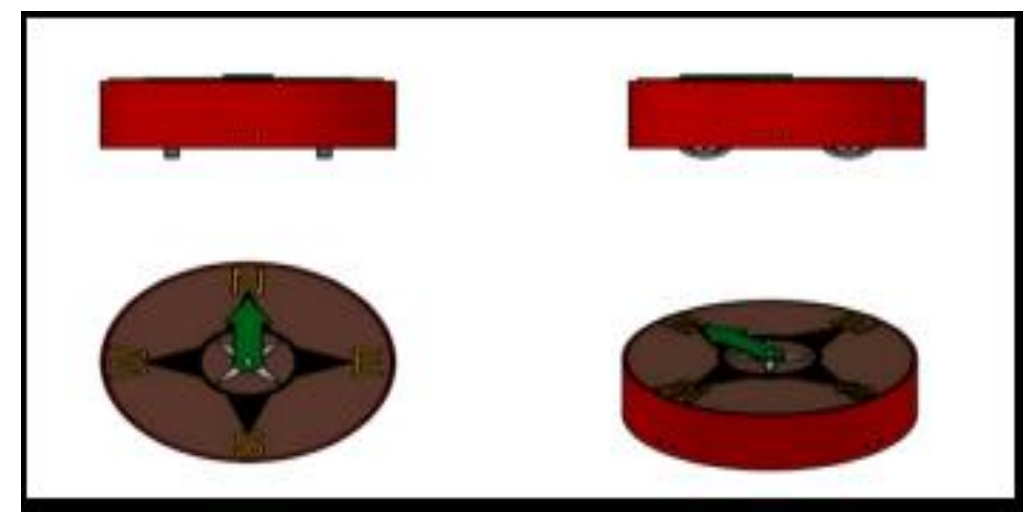

\section{Basic Movement}

This portable GeoBot moves using four wheels that are capable of forward, backward, left, right and rotating movements. The advantage of GeoBot mobile is the wireless connection which is the bluetooth technology. To facilitate the use of GeoBot, this wireless connection can be done using the 'Dabble' application which can be downloaded to android smartphones.

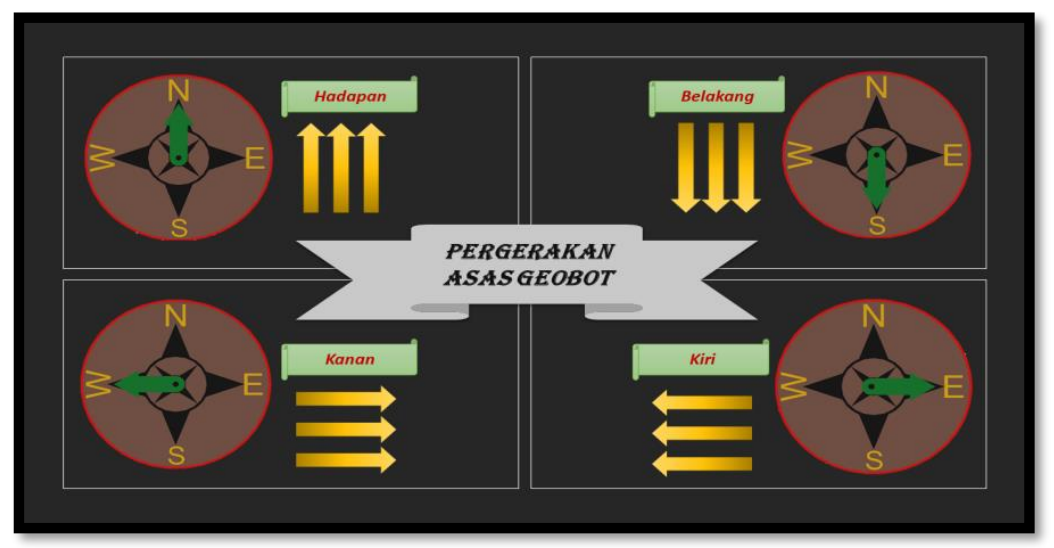




\section{GeoBot Components}

GeoBot mobile technically uses components as shown in the table below.

Table 1: Geobot Components

\begin{tabular}{ll}
\hline No. & \multicolumn{1}{c}{ Components } \\
\hline 1 & Arduino Board \\
2 & Motor Driver L298 \\
3 & N20 DC Motor With wheel \\
4 & Rechargeable Battery \\
5 & Bluetooth Module \\
6 & Servo 360 Degree Rotation \\
7 & LED lights \\
\hline
\end{tabular}

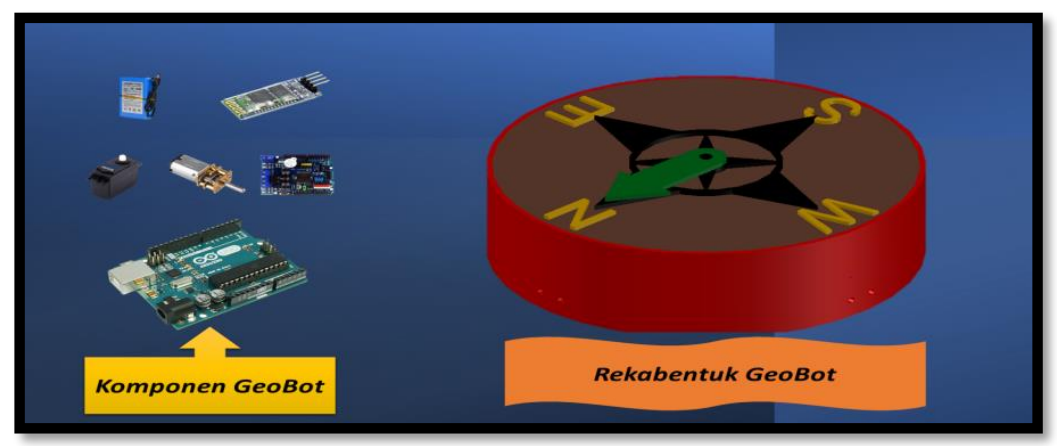

\section{Coding Using Pictoblox Software}

PictoBlox software is the core of moving GeoBot using 'Scratch and Block Programming' method. The first block of code is to activate the 'Arduino UNO' Microcontroller and also perform GeoBot communication and the smartphone application 'Dabble'. This wireless communication uses 'Bluetooth' to facilitate GeoBot control.

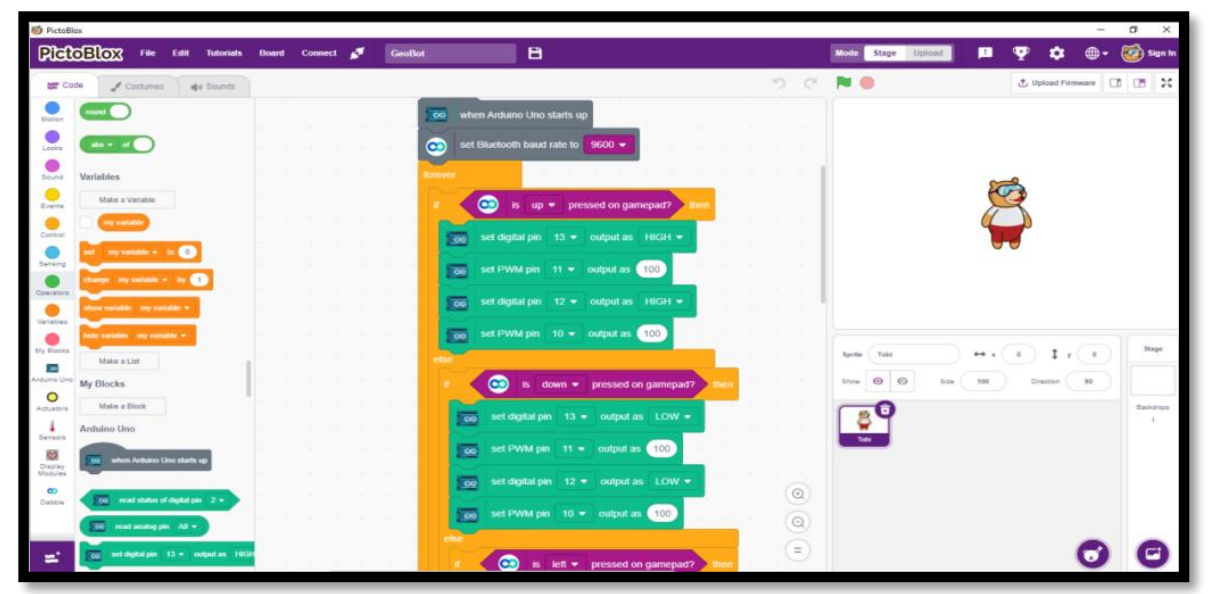




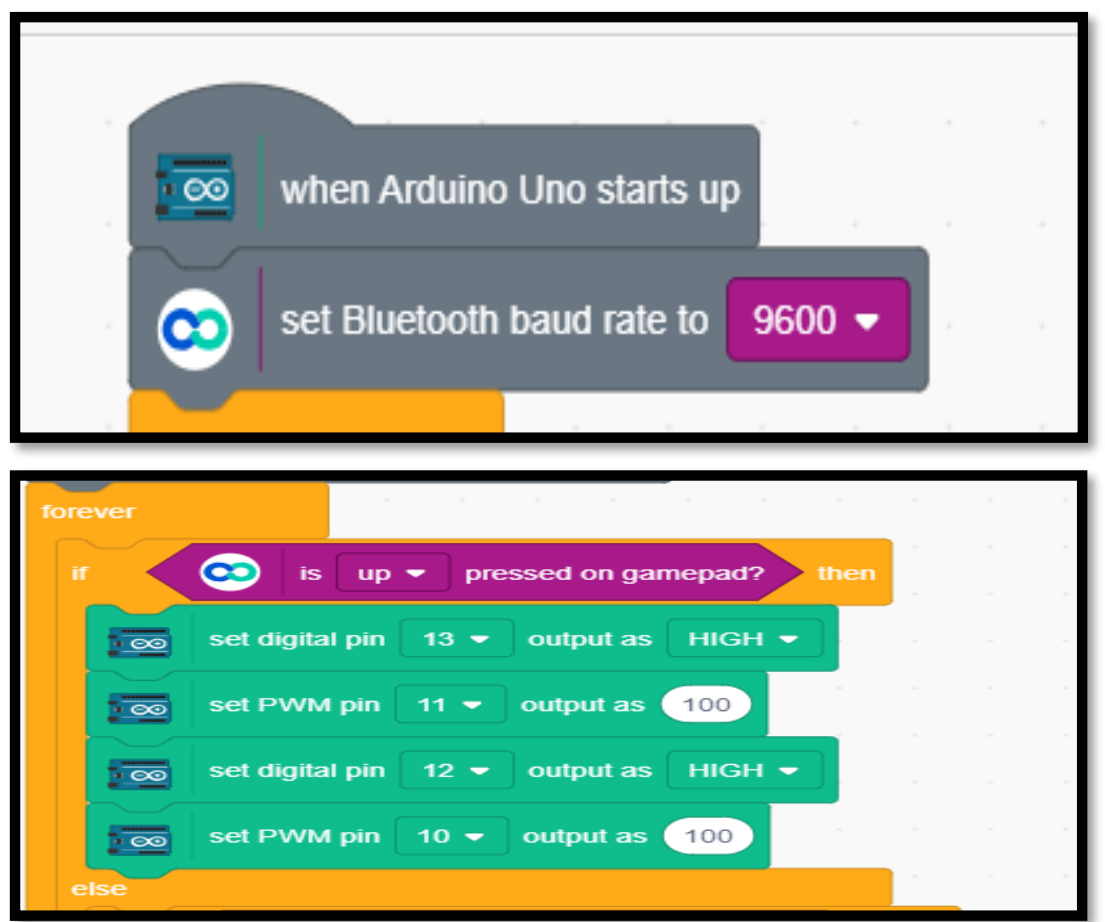

The next block describes the command that the Arduino UNO microcontroller will send to the Motor that drives the GeoBot. Referring to the diagram above, the command is a forward movement when the upward pointer game pad is pressed.

Technically, the four pins used on the Arduino UNO microcontroller are pins 10,11,12 and 13. While the speed level has been set to $100 \%$.

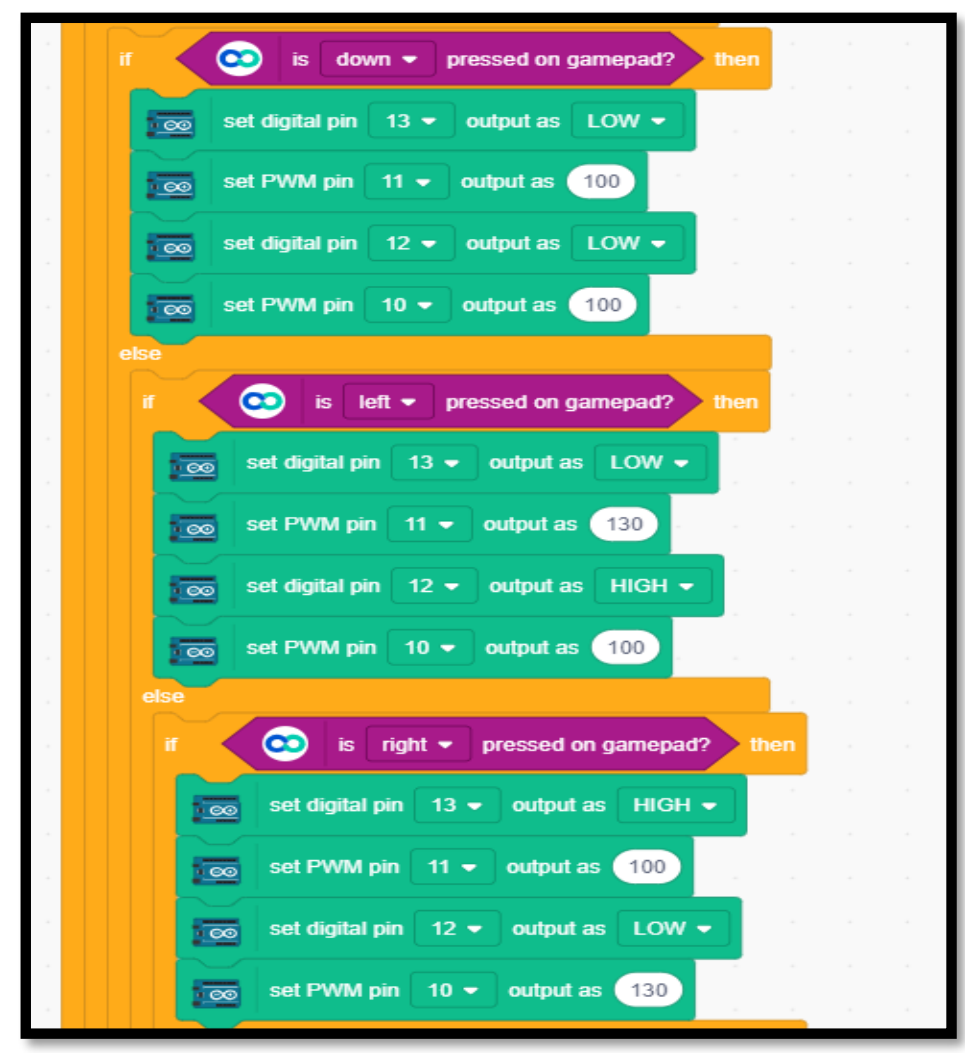


It is same goes for the next block of code which is the backward, left and right movement of the GeoBot.

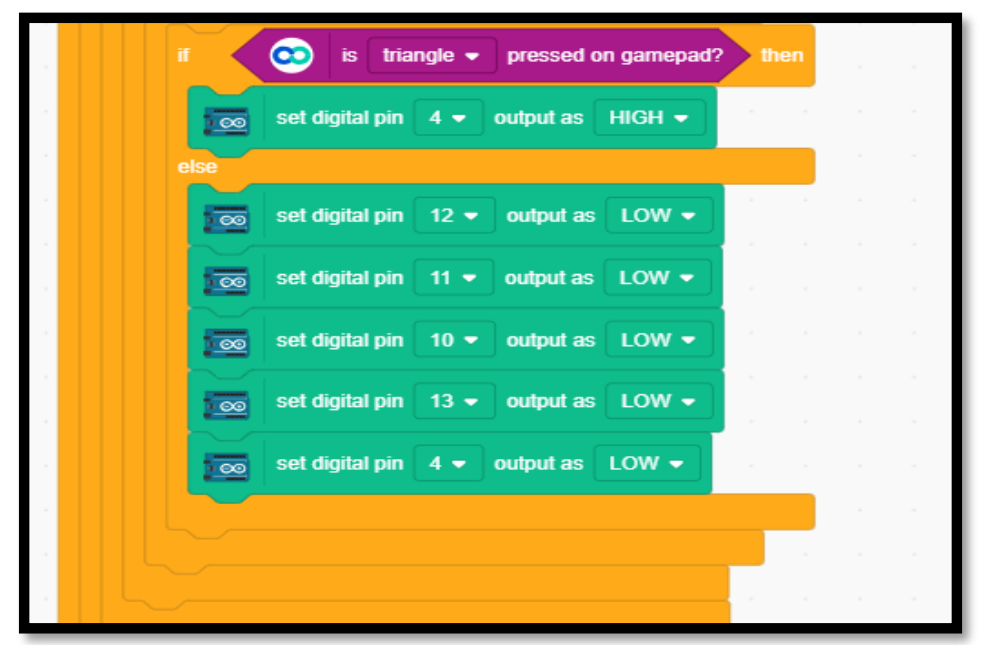

While on the last block of code, the triangular hint on the 'Dabble' app game pad serves as the Hon/buzzer sound on the Geobot. Next, digital pins 10,11,12,13 and 4 are encoded at the LOW signal command to turn off any GeoBot movement if the game pad is not pressed

\section{Theories and Models in Geobot Games}

Theories and models are important for designing the method of the Geographic Skills Geobot game module. For the method's development, the theories and models used are as follows:

\section{Goal Orientation Theory}

The researchers interpret goal orientation as individual goals implicitly when they seek achievement based on specific performance and assert that goals are intended to engage in a task, and the types of targets adapted and used in creating a framework of work (Dweck \& Leggett 1988). Therefore, goal orientation theory is generally considered a more comprehensive way to understand the reasons of the students engage in an academic assignment using Geobot games.

\section{Vygotsky's Theory of Social Constructivism}

The social theory of constructivism is knowledge -related that emphasizes the development of knowledge in humans constructed through interaction with each other (Vygotsky, 1978). The social constructivism approach focuses on the social context with mastery of the content of learning collectively through interactions that exist in pre -formed groups (Crawford, 1996). The exchange of information and ideas allows students to improve their understanding of a learning topic with the involvement of each student in the mastery of the content (Crawford, 1996). This approach is the best platform to develop students' thinking in the learning process. This theory was founded by Lev Semenovich Vygotsky who was a Russian psychologist (Makgato, 2012).

\section{ARCS Motivation Model}

ARCS is a systematic model for designing game robot -assisted instruction by emphasizing four important motivational factors namely (i) attention, (ii) relevance, (iii) confidence, and satisfaction (Keller \& Kopp, 1987). 
DOI: https://doi.org/10.47405/mjssh.v6i6.820

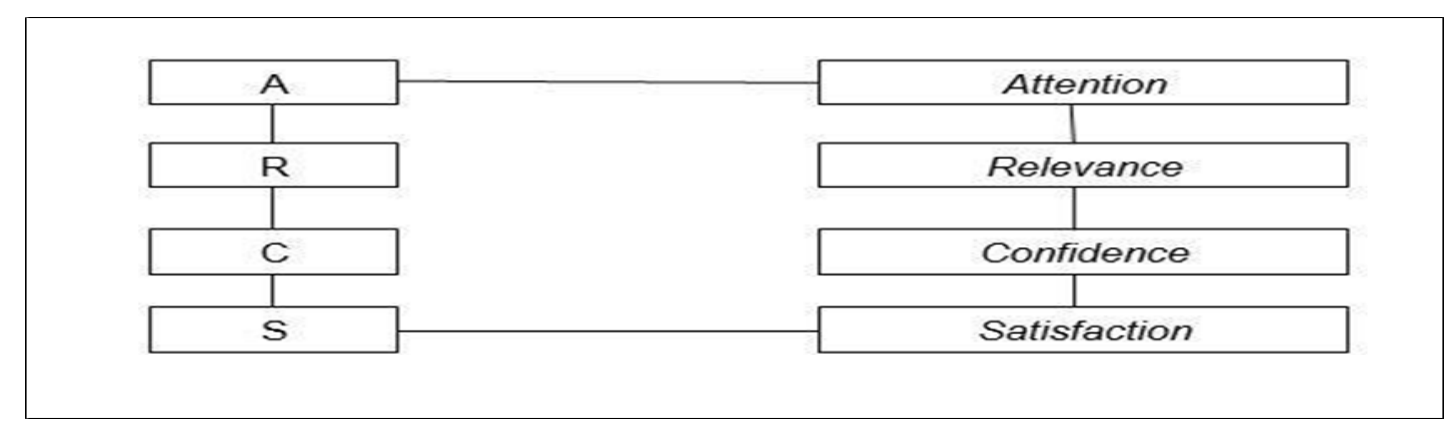

\section{Technology Acceptance Model}

The Technology Acceptance Model (TAM) was developed by Davis, Bagozzi, \& Warshaw (1989). It is a combination of several behavioral theories and is used specifically in the implementation of technology. In this model, the readiness and acceptance of a technology is a main factor to determine the success of the technology implementation in a certain activity. The implementation of technology that is not provide any added value in an activity is considered unsuccessful (Davis et al., 1989).

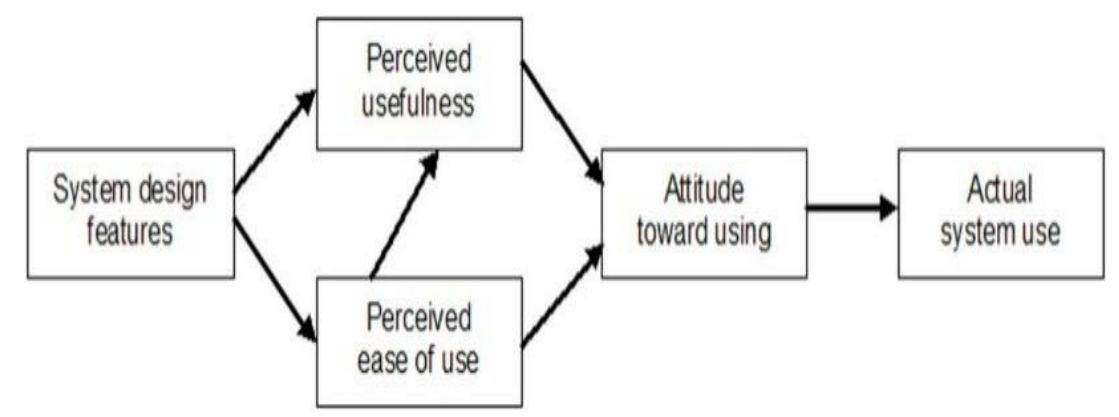

\section{Implementation strategy Geobot game}

There are four other aspects that emphasized in the implementation strategy of Geobot game module during the field study; namely teacher selection, teacher training, implementation sessions and assessment for students.

\section{Teacher Selection}

Teachers involved in teaching the study subjects of the topic of Geography Skills who will use the Geobot module are on their own volition to be fully involved in this study. The timetable of the teachers involved will not be disturbed by the implementation of the study taking the real time of Geography subjects that have been set by their respective schools. All teachers involved have 3 hours of teaching time per week based on the time allocation in the Secondary School Standard Curriculum (KSSM). The researcher will keep the same teacher in the classroom in order to avoid the discomfort of students if they get a new teacher. This is because students need to adapt to the environment that will be created by the new teacher which in turn may affect the results of the study. All selected teachers have taught over 3 years in the subject of Geography and have a bachelor's degree in Geography education as a minimum qualification. This indicates the background of teaching experience and the level of teacher education are equivalent. The researcher will give a briefing related to the study to all teachers involved in this study in their respective schools. 


\section{Training for Teachers}

Training will be provided to the teachers in their respective schools. 7 hours will be allocated in a day making a total of 21 hours for training involving 3 days. Aspects that will be given training involve technical, Autocad software and how the Geobot game is played.

\section{Implementation Session}

A printed module will be provided to all teachers to facilitate the learning process of the Geobot Geography Skills game. Geobot games will be implemented in the classroom while students go through the process of learning Geography Skills.

\section{Evaluation and Measurement}

Measurements will be performed three times involving pre -test, post -test 1 and post -test 2 . The instrument used will evaluate goal orientation, collaborative level and students' achievement after using the Geobot Games module teaching module.

\section{3) Development}

This stage involves building a real system using all the media and technology elements selected based on the requirement. It is built based on analysis and design phases. The purpose of this phase is to produce lesson plans and learning materials. While this phase will be developed, the teaching steps as well as the media to be used in teaching and other documents are required. The output in the design phase will be the input to the development phase. Geobot game project development work will be done according to the agreed requirements specifications. Each development will be tested so that it is consistent and can operate effectively.

Here are some aspects of development in this phase that will be discussed;

\section{Daily Teaching Plan (DTP/RPH)}

The researcher will construct a Daily Teaching Plan (DTP/RPH) for the treatment group (experimental) based on the Standard Secondary School Curriculum adapted to the Geobot game activities shown in table 2 below.

Table 2: Geography Skills Daily Lesson Plan

\begin{tabular}{lll}
\hline Fields/Topics/Subtopics & $\begin{array}{l}\text { Lesson hours a Total DLP and Activities } \\
\text { week }\end{array}$ \\
\hline 1.1 Direction And Position In Topographic Map & 4 & 2 \\
1.2 Scale, Distance And Area In Topographic Maps & 4 & 2 \\
$\begin{array}{l}\text { 1.3 Elevation And Cross Section In Topographic Maps } \\
\text { 3 }\end{array}$ & 1 \\
$\begin{array}{l}\text { 1.4 Physical Land View And Cultural Land View In } \\
\text { Topographic Maps }\end{array}$ & 5 & 2 \\
\hline Time total & 16 & 7 \\
\hline
\end{tabular}

\section{Geobot Game Robot Manual}

The developed Geobot Geography Skills game manual contains 7 games activities. Each game represents subtopics in Geographic Skills namely Direction and Position in Topographic Map (2 games), Scale, Distance and Area in Topographic Map (2 games), Elevation and Cross Section in 
Topographic Map (1 game) and Physical Land View and Land View Culture In Topographic Map (2 games). The manual comes with a guide to use the modules, module goals and every game details for each level.

\section{Geobot Game Measuring Tool}

The researchers have developed a Geographic Skills achievement test instrument and two adapted questionnaires namely Pattern of Adaptive Learning Scale (PALS) and 21stCLD Student Work Rubric on Collaboration to measure the goal orientation and level of collaboration of students towards learning materials namely Geobot Game Module.

\section{Geobot Game Activities}

The game activities developed in the Geography Skills Geobot game module are as in the table below;

Table 3: Geobot Game Activities

\begin{tabular}{|c|c|c|}
\hline No. & Activities & Learning standards \\
\hline 1 & Robot and S4A & Geobot Encoding \\
\hline 2 & Finding Treasure Locations Part 1. & $\begin{array}{l}\text { 1.1.1 Identify the eight major wind directions. } \\
\text { 1.1.2 Determine the direction of a location in a } \\
\text { topographic map. }\end{array}$ \\
\hline 3 & Finding Treasure Locations Part 2. & $\begin{array}{l}\text { 1.1.3 Use } 4 \text {-digit and } 6 \text {-digit grid references to } \\
\text { determine position in a topographic map. } \\
\text { 1.1.4 Measure the bearing grid of a location in a } \\
\text { topographic map. }\end{array}$ \\
\hline 4 & $\begin{array}{l}\text { Long walks increase knowledge } \\
\text { Part } 1\end{array}$ & $\begin{array}{l}\text { 1.2.1Describe the types of scales in topographic } \\
\text { maps. } \\
\text { 1.2.2Distinguish between statement scales, straight } \\
\text { scales and representative fractions. }\end{array}$ \\
\hline 5 & $\begin{array}{l}\text { Long walks increase knowledge } \\
\text { Part } 2\end{array}$ & $\begin{array}{l}\text { 1.2.3Demonstrate how to measure distances based } \\
\text { on scales in a topographic map. } \\
\text { 1.2.4Demonstrate how to calculate an area based } \\
\text { on a scale in a topographic map. }\end{array}$ \\
\hline 6 & Flashback & $\begin{array}{l}\text { 1.3.1Identify altitude based on symbols in a } \\
\text { topographic map. } \\
\text { 1.3.2Draw a cross section based on contour lines. } \\
\text { 1.3.2Distinguish the shape of the earth's surface } \\
\text { based on cross section. }\end{array}$ \\
\hline 7 & Correlations Part 1 & $\begin{array}{l}\text { 1.4.1Identify physical landform features and } \\
\text { cultural landform features. } \\
\text { 1.4.2Describe physical land view features and } \\
\text { cultural land view features based on symbols in } \\
\text { topographic maps. }\end{array}$ \\
\hline 8 & Correlations Part 2 & $\begin{array}{l}\text { 1.4.3Analyze the relationship between physical } \\
\text { land view features and cultural land view features } \\
\text { in topographic maps. }\end{array}$ \\
\hline
\end{tabular}

\section{4) Implementation}

At this stage, the teaching materials that have been prepared will be used or implemented in real situations. The completed multimedia projects will be tested on real users to identify errors during the 
project development process. In the event of an error, modifications will be made before it is fully handed over to the target user for use. Before the actual implementation was done, a pilot study on the use of this module was conducted at Sekolah Menengah Kebangsaan Pitas involving 31 students. The actual study procedure took 11 weeks but the intervention was only implemented for 8 weeks which started in the third to tenth week. This time period is sufficient because previous studies related to quasiexperimental intervention studies were implemented in the range of 8 to 16 weeks (Schimidt et al., 2009). Pre -test was given to all students in the first week, while post -test 1 was administered in the ninth week as well as post -test 2 in the eleventh week.

\section{5) Evaluation}

The assessment is divided into two parts, which are formative assessment and summative assessment. Formative assessment covers each phase in the ADDIE process. Formative evaluation should be done at all levels to ensure its effectiveness. Summative evaluation only involves specific test designs that require user feedback such as content, strategies and multimedia elements through methods such as interviews, questionnaires, supervision and testing. Summative assessment usually occurs at the final stage of a completed teaching material production project.

\section{Validity and Reliability of the Geobot Game Module}

A pilot study was conducted on a sample of form four students in one of the secondary schools in Pitas district. The selection of the pilot study sample had homogeneous characteristics with the actual study population. The determination of the number of pilot study samples according to Johnson \& Christensen (2012) ranged from 10 to 40 people. Whereas Hertzog (2008) argues for the number of pilot study samples for experimental study design between 25 to 48 people. Therefore, in this study, a total of 31 students were involved as a sample in the pilot study by following the Geobot game activities in the classroom for seven weeks, which is seven meetings equivalent to 9 hours of meetings. The study sample followed 7 activities over seven meeting sessions. Upon completion of seven meetings, study subjects took and answered the Geobot module reliability questionnaire. The minimum level used in this analysis was the value of the Cronbach's Alpha reliability coefficient of .70 according to the recommendations of Fraenkel et al. (2012).

Table 4: Cronbach's Alpha Values of Geobot Game Modules

\begin{tabular}{llll}
\hline DLP & Activities & Alpha Cronbach & No. Of Item \\
\hline 1 & Finding Treasure Locations Part 1. & .718 & 4 \\
2 & Finding Treasure Locations Part 2. & .729 & 4 \\
3 & Long walks increase knowledge Part 1 & .805 & 4 \\
4 & Long walks increase knowledge Part 1 & .742 & 4 \\
$5 \& 6$ & Flashbacks & .734 & 4 \\
7 & Correlations 1 & .725 & 4 \\
8 & Correlations 2 & .789 & 4 \\
\hline & Total = .959 & \\
\hline
\end{tabular}

All game types showed a Cronbach's Alpha value above .70, while the overall value was .959. The ideal value for reliability should exceed 0.7 (Pallant, 2010). Therefore, the Geobot game module of the topic of Geographical Skills has an acceptable reliability value for continuing the study.

Besides, the researcher used 3 Excellent Geography Teachers DG (44-48) who have been appointed by the MOE as subject matter expert teachers in Geography form 4 and 5 as experts to respond to the modules that have been built. All three teachers have 15 years of teaching experience in teaching Geography at SPM level and have been heavily involved in academic improvement programs such as being course speakers on teacher pedagogy, examiners and also producing PDPc innovations. The panel 
DOI: https://doi.org/10.47405/mjssh.v6i6.820

of experts involved in evaluating the face validity and content validity of the Geobot Game Module are listed in the following Table 5:

Table 5: Geobot Game Module Validity Experts

\begin{tabular}{ccc}
\hline Expert & $\begin{array}{c}\text { Position and Teaching } \\
\text { Exprience }\end{array}$ & Expertise \\
\hline Expert 1 & $\begin{array}{c}\text { Excellent Teacher for } \\
\text { Geography, 19 Years }\end{array}$ & $\begin{array}{c}\text { SPM Pedagogy, Pdpc } \\
\text { Innovation and Geo SPM }\end{array}$ \\
& Examiner \\
Expert 2 & Excellent Teacher for & SPM Pedagogy, Pdpc \\
& Geography, 15 Years & Innovation and Geo SPM \\
Expert 3 & Excellent Teacher for & Examiner \\
& Geography, 21 Years & SPM Pedagogy, Pdpc \\
& & Innovation and Geo SPM \\
& & Examiner \\
\hline
\end{tabular}

This panel of experts will evaluate the validity of the Geobot Game Module using a questionnaire developed by the researcher modified from the Game Robot Module module reliability questionnaire (Shakir, 2018) which stipulates the validity of the module must meet the following five validity conditions:

i. Meet population targets.

ii. The teaching situation and method of module implementation are satisfactory.

iii. The time taken to complete the module is sufficient.

iv. Successfully improve student's achievement.

v. Successfully change the student's attitude towards excellence performance .

In order to determine whether this game robot module has good content validity, then the view of Tuckman and Waheed (1981) is taken into account which states that a mastery or achievement level of 70 percent is considered to have mastered a high level of achievement. Therefore, the module in this study will be evaluated based on its percentage value using the following formula:

Total expert score X $100 \%=$ Content Validity Achievement

Maximum score

The Geobot Game module and the module validity questionnaire form were distributed to an expert panel appointed by the researcher. Thus, the researcher made improvements based on the recommendations and suggestions of the expert panel to ensure that the Geobot Game Module can be used smoothly and effectively during the PDPc for the topic of Geographical Skills is conducted. The results of the questionnaire of the expert panel are shown in table 6.

Table 6: Validity Findings of Geobot Gamification Module

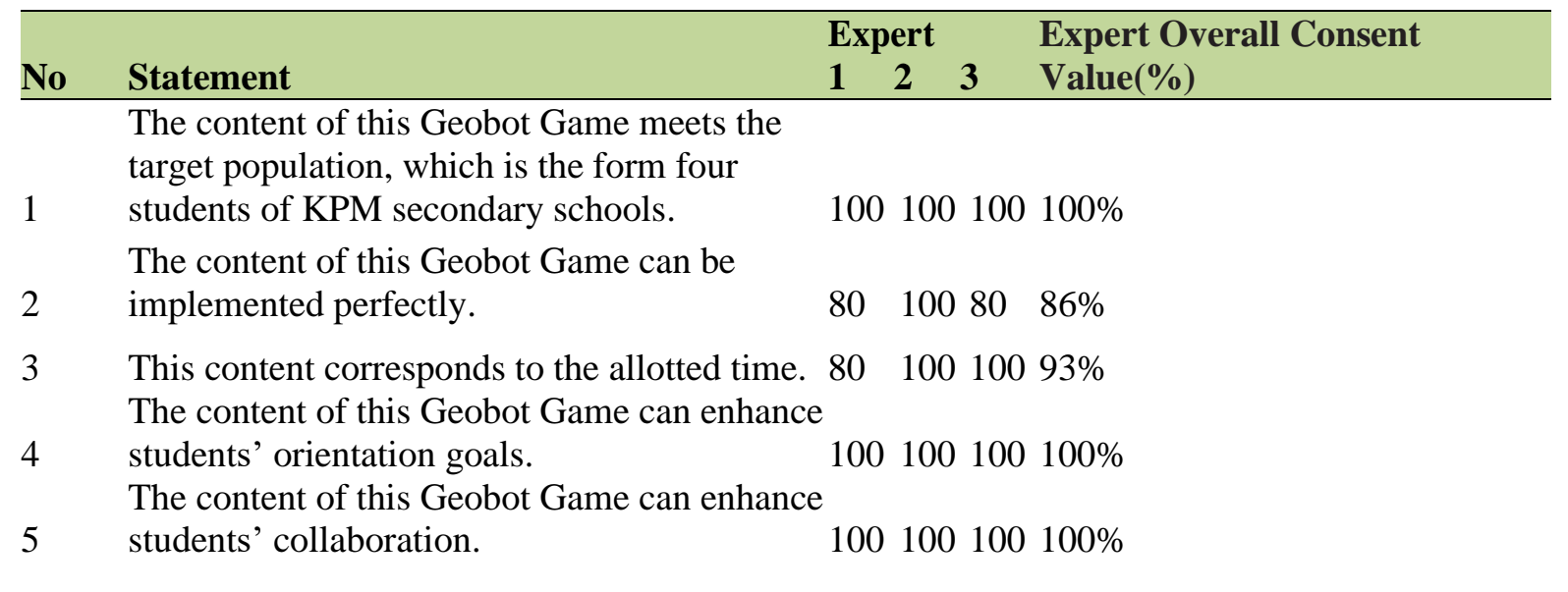


The content of this module can improve students' achievement.

The content of this module can enhance students 'digital literacy.

$80 \quad 10010093 \%$

The agreement value of this expert panel exceeds $70 \%$ and in general the content validity value for activities in the Geobot game Module exceeds the good level. Thenceforth, the researcher made some improvements as suggested by the validating expert as in Table 7.

Table 7: Geobot Game Module Improvements

\begin{tabular}{lll}
\hline Expert & $\begin{array}{l}\text { Recommendations/Expert } \\
\text { Recommendation }\end{array}$ & Improvement \\
\hline Expert 1 & $\begin{array}{l}\text { For the Proficiency Level 6 } \\
\text { Performance Standard, questions can be } \\
\text { added further in each Geobot activity. }\end{array}$ & $\begin{array}{l}\text { The researcher rearranged the } \\
\text { questions for each Geobot } \\
\text { games activity to achieve the } \\
\text { Mastery Level Standard } 6 .\end{array}$ \\
Expert 2 & $\begin{array}{l}\text { Geobots can be patented for use by } \\
\text { Geography teachers. }\end{array}$ & $\begin{array}{l}\text { Researchers will seek the } \\
\text { advice of Supervisors or those } \\
\text { with experience in the process } \\
\text { of patenting Geobot modules. }\end{array}$ \\
Expert 3 & $\begin{array}{l}\text { Researchers will participate in } \\
\text { innovation } \\
\text { pe expanded and marketed to be more } \\
\text { user -friendly. }\end{array}$ & $\begin{array}{l}\text { for the purpose of further } \\
\text { developing the potential of } \\
\text { robot games in education. }\end{array}$ \\
\end{tabular}

\section{Discussion}

The Geobot game module is a module that uses the DSKP Geography form four secondary schools (Ministry of Education Malaysia, 2018) as a reference and guide in planning PdPc activities for each game session in this module. In addition, this module focuses more on the level variables of goal orientation, collaborative and achievement of form four students in the topic of Geographical Skills. Researchers suggest that in the future, this Geobot game can be expanded into other topics to increase students' interest and motivation towards the subject of Geography as a whole.

\section{Summary}

The development of the Form Four Geography Skills Geobot game module based on the ADDIE model teaching design model which involves five phases makes research and development done more systematically to produce more effective modules that can be used in teaching and learning the topic of Form Four Geography Skills. Apart from that, the Geobot game also fully complies with the curriculum set by the Ministry of Education Malaysia based on the Form Four Geography Textbook and the Curriculum and Assessment Standard Document (DSKP).

\section{References}

Branch, R. M. (2009). Instructional design: The ADDIE approach (Vol. 722). USA: Springer Science \& Business Media.

Buku Teks Geografi Tingkatan Empat, (2019). Kementerian Pendidikan Malaysia. Kubu Publications. Crawford, K. (1996). Vygotskian Approaches in Human Development in The Information Era. Educational Studies in Mathematics, 31(1-2): 43-62. 
Davis, F. D., Bagozzi, R., \& Warshaw, P. (1989). User acceptance of computer technology: a comparison of two theoretical models. Management Science, 35, 181-192.

Dweck, C. S., \& Leggett, E. L. (1988). A Social-Cognitive Approach to Motivation and Personality. Psychological review, 95(2), 256.

Gee, J. P. (2007). Good video games good learning: Collected essays on video games, learning, and literacy. New York, NY: P. Lang.

Jusuf, H. (2016). Penggunaan Gamifikasi dalam Proses Pembelajaran. Jurnal TICom, 4(3), 92772.

Rosly, M. R., \& Khalid, F. (2017). Gamifikasi: Konsep dan implikasi dalam pendidikan. Pembelajaran Abad ke-21: Trend Integrasi Teknologi, 144-154.

Hertzog, M. A. (2008). Considerations in Determining Sample Size for Pilot Studies. Research in Nursing dan Health. 31(2), 180-191.

Keller, J.M., \& Kopp, T. (1987). Application of the ARCS model of motivational design. In C.M.

Reigeluth(Ed.), Instructional theories in action: Lessons illustrating selected theories and models. Lawrence Erlbaum Associates, U.S.A.

Johnson, B. \& Christensen, L. (2012). Educational research. 4th. Los Angeles: Sage.

Kupasan Mutu Jawapan SPM (2013). Lembaga Peperiksaan Malaysia.

Kupasan Mutu Jawapan SPM (2014). Lembaga Peperiksaan Malaysia.

Makgato, M. (2012). Identifying Constructivist Methodologies and Pedagogic Content Knowledge In The Teaching And Learning Of Technology. Procedia Social and Behavioral Science. 47: 1398-1402.

Midgley, C., Maehr, M. L., Hruda, L. Z., Anderman, E., Anderman, L., Gheen, K. E., Kaplan, A. Kumar, R. Middleton, M. J., Nelson, J. Roeser, R. Urdan, T. (2000). Manual for the Patterns of Adaptive Learning Scales. Ann Arbor, MI: University of Michigan.

Muhammad Shakir Saad. (2018). Keberkesanan Proses Pembelajaran Robot Permainan Terhadap Pencapaian, Komunikasi Berkesan Dan Motivasi Pelajar Topik Respirasi Sel. Tesis UMS.

Ortiz, A.M. (2015). Examining Students' Proportional Reasoning Strategy Levels As Evidence Of The Impact Of An Integrated Lego Robotics And Mathematics Learning Experience. Journal of Technology Education. 26(2): 23-28.

Pallant, J. (2010). SPSS survival manual: A step by step guide to data analysis using SPSS (4 th ed). Maidenhead: Open University Press/McGraw-Hill.

Richey, R. C., \& Klein, J.D. (2009). Design and Development Research Methods, Strategies, and Issues. New York: Routledge.

Robinson, K. (1972). The Task-Achievement Analysis of Education. Educational Philosophy and Theory, 4:2, 17-24, DOI: 10.1111/j.1469- 5812.1972.tb00052.x .

Rusell, J.D. (1974). Modular instruction: A guide to the design, selection, utilization and evaluation of modular materials. New York: Publishing Company.

Schmidt, H.G., Van der Molen, H.T., Te Winkel, W.W.R., \& Winjen, W.H.F.W. (2009). Constructivist, problem-based learning does work: meta-analysis of curricular comparisons involving a single medical school. Educational Psychologist, 44 (4): 227-249.

Sidek Mohd Noah. (2005). Pembinaan modul: bagaimana membina modul latihan dan modul akademik. Serdang: UPM.

Škuta, P., \& Kostolányová, K. (2018). Adaptive aproach to the gamification in education. DIVAI 2018.

Sulaiman, Noorul \& Shahrill, Masitah. (2015). Engaging Collaborative Learning to Develop Students' Skills of the 21st Century. Mediterranean Journal of Social Sciences. $6 . \quad 544-552$. 10.5901/mjss.2015.v6n4p544.

Tan,W.H. (2018). Gamifikasi Dalam Pendidikan: Pembelajaran Berasaskan Permainan. Tanjong Malim: Universiti Pendidikan Sultan Idris.

Tuckman, B.W, \& Waheed, M.A. (1981). Evaluating and individualized science programme for community college students. Journal of Research in Science Teaching, 18: 489-495.

Vygotsky, L. S. (1978). Mind in Society. (Trans. by Cole, M.), Cambridge, MA: Harvard University Press.

Vygotsky, L.S. (1981). The Genesis Of Higher Mental Functions. Dalam J. V. Wertsch (ed.). The concept activity in soviet psychology armonk. New York: Sharpe., hlm. 144-188. 